MERCATORIA

Available online http://ojs.uma.ac.id/index.php/mercatoria

\title{
Perbandingan Diversi dan Restorative Justice terhadap Anak Berhadapan dengan Hukum di Kota Medan dan Kabupaten Deli Serdang
}

\author{
Lidya Rahmadani Hasibuan * \\ Universitas Pembangunan Pancabudi Medan \\ *Corresponding author: E-mail: lidva.hsb@gmail.com
}

\begin{abstract}
Abstrak
Diversi dan Restorative Justice merupakan metode penyelesaian di luar proses peradilan pidana yang bertujuan untuk kembali memulihkan tatanan kehidupan masyarakat yang dirusak oleh kejahatan. UU No. 11 Tahun 2012 memberikan dasar hukum yang kuat untuk pelaksanaan Restorative Justice pada penyelesaian kasuskasus anak, agar anak yang berhadapan dengan hukum tidak langsung diproses secara hukum tetapi lebih menekankan pada kepentingan terbaik bagi anak dan hukum pidana sebagai upaya terakhir bagi anak. Pasal 7 ayat (2) UU No. 11 Tahun 2012 tentang Sistem Peradilan Pidana Anak menyatakan bahwa penegak hukum wajib melakukan Diversi dengan pendekatan Restorative Justice terhadap anak yang berhadapan dengan hukum.
\end{abstract}

Kata Kunci : Diversi, Restorative Justice, dan anak yang berhadapan dengan hukum

\begin{abstract}
Diversi and Restorative Justice is a method of settlement outside the criminal justice process that aims to rerestore the order of life of people who are destroyed by crime. Law No.11 of 2012 provides a strong legal basis for the implementation of Restorative Justice on the settlement of child cases, so that children facing the law are not directly processed legally but rather emphasize the best interests of children and criminal law as a last resort for children . Article 7 Paragraph (2) of Law No.11 Year 2012 on the Criminal Justice System of Child states that law enforcement is obliged to conduct Diversi with Restorative Justice approach against children in conflict with law.
\end{abstract}

Keyword: Diversi, Restorative Justice, and children facing the law

How to Cite: Hasibuan. L.R., (2017), Perbandingan Diversi dan Restorative Justice terhadap Anak Berhadapan dengan Hukum di Kota Medan dan Kabupaten Deli Serdang, Mercatoria, 10 (2): 128-136. 


\section{PENDAHULUAN}

Perlindungan anak merupakan suatu upaya untuk menciptakan kondisi dimana anak dapat melaksanakan hak dan kewajibannya. Berdasarkan konsep parents patriae, yaitu negara memberikan perhatian dan perlindungan kepada anakanak sebagaimana layaknya orang tua kepada anak-anaknya, maka penanganan anak-anak yang berhadapan dengan hukum juga harus dilakukan demi kepentingan terbaik bagi anak serta berpijak pada nilai-nilai Pancasila. ${ }^{1}$

Undang-undang Dasar Negara Republik Indonesia Tahun 1945 pada Pasal 34 Amandemen ke IV menegaskan bahwa , "fakir miskin dan anak-anak terlantar dipelihara oleh Negara". Hal ini menunjukan adanya perhatian serius dari pemerintah berkaitan dengan persoalan perlindungan anak.

Hukum Islam juga memberikan pengertian tentang seorang anak. Harta dan anak-anak adalah perhiasan kehidupan dunia, dan amal sholeh yang kekal adalah sebaik-baik pahala disisi Tuhan mu dan sebaik-baik cita-cita (QS. Al-Kahfi 18:46) ${ }^{2}$.

Berdasarkan data awal terdapat lebih dari 7000 (tujuh ribu) anak sebagai pelaku tindak pidana masuk proses peradilan setiap tahun. Bulan Juli 2010 terdapat 6.273 (enam ribu dua ratus tujuh puluh tiga) anak yang berada di Tahanan serta Lapas di seluruh Indonesia, terdiri dari 3.076 (tiga ribu tujuh puluh enam) anak dengan status tahanan, 3.197 (tiga

${ }_{1}$ Nur Rochaeti, Model Restorative Justice sebagai Alternatif Penanganan bagi Anak Delinkuen di Indonesia, 2008 MMH Jilid 37 No. 4, Desember, hlm. 239.

2 Nazri Adlany dkk, Al Quran dan Terjemah Indonesia, 2005, cetakan ke 8, PT.Sari Agung, Jakarta, hlm. 560 . ribu seratus sembilan puluh tujuh) narapidana dan 56 (lima puluh enam) anak negara. ${ }^{3}$ Hal ini menunjukkan bahwa pemidanaan yang diatur dalam Undangundang Pengadilan Anak masih lemah. Banyaknya putusan pengadilan anak yang cenderung menjatuhkan pidana penjara daripada tindakan terhadap anak nakal, sebenarnya tidak sesuai dengan filosofi dari pemidanaan dalam hukum pidana anak.

KOMNAS Anak pada Tahun 2011 menerima 1.851 pengaduan anak yang berhadapan dengan hukum (anak sebagai pelaku tindak pidana) yang diajukan ke pengadilan. ${ }^{4}$ Angka ini meningkat dibanding pengaduan pada tahun 2010, yakni 730 kasus. Hampir 52 persen dari angka tersebut adalah kasus pencurian diikuti dengan kasus kekerasan, perkosaan, narkoba, perjudian, serta penganiayaan dan hampir 89,8 persen kasus anak yang berhadapan dengan hukum berakhir pada pemidanaan atau diputus pidana. Gambaran kondisi tersebut menjadi kondisi yang melandasi upaya melakukan penelitian di Pengadilan Negeri Stabat sebagai pilot projek pelaksanakan Diversi sebelum UU No. 11 Tahun 2012 tentang Sistem Peradilan Pidana Anak.

Diversi dan Keadilan Restoratif menjadi dasar dari pembaharuan sistem peradilan pidana dalam pelaksanaan sistem peradilan pidana anak, yang dapat dilihat di dalam Undang-undang Nomor 11 Tahun 2012 tentang Sistem Peradilan

\footnotetext{
3Harian orbit, $11 \quad$ Maret 2013 http://www.harianorbit.com/sulit-menangani-anakyang-berhadapan-dengan-hukum/

4 Komisi Nasional Anak, 21-12-2011. "Catatan Akhir Tahun 2011 Komisi Nasional Perlindungan Anak". www.komnasanak.com, diakses tanggal 29 Januari 2014.
} 
Lidya Rahmadhani Hasibuan, Perbandingan Diversi dan Restorative Justice terhadap Anak Berhadapan dengan Hukum di Kota Medan dan Kabupaten Deli Serdang

Pidana Anak, yang bertujuan untuk menghindari anak pelaku tindak pidana dari jerat hukuman atau pemidanaan, kedua konsep tersebut merupakan hal baru bagi masyarakat Indonesia.

Konsep diversi dan restorative justice dalam pelaksanaannya melibatkan pihak ketiga di dalam penyelesaian masalah antara anak yang melakukan dan anak yang menjadi korban dalam tindak pidana tersebut, dengan melibatkan masingmasing keluarga mereka, serta pihakpihak lain, dengan tujuan proses penyelesaian perkara diusahakan agar anak pelaku tindak pidana jauh dari proses pemidanaan terhadap anak pelaku tindak pidana. Ketentuan baru ini telah sesuai dengan Konvensi Hak-Hak Anak dan Beijing Rules yang menekankan bahwa upaya Diversi harus diprioritaskan dalam penanganan Anak, hal ini berguna untuk menjauhkan anak dari penyelesaian dengan sistem peradilan pidana yang cenderung memberikan dampak negatif bagi anak. ${ }^{5}$

Restorative justice memiliki tanggapan atau reaksi terhadap perilaku delikuensi anak tidak akan efektif tanpa adanya kerjasama dan keterlibatan dari korban, pelaku dan masyarakat. Prinsip yang menjadi dasar ialah bahwa keadilan paling baik terlayani, apabila setiap pihak menerima perhatian secara adil dan seimbang, aktif dilibatkan dalam proses peradilan dan memperoleh keuntungan

5Barda Nawawi Arief, Bunga Rampai Kebijakan Hukum Pidana: (Perkembangan Penyusunan Konsep KUHP Baru, 2008 ,Edisi Pertama, Cetakan ke-1, Kencana Prenada Media group, Jakarta, hlm.23. secara memadai dari interaksi mereka dalam sistem peradilan anak. ${ }^{6}$

\section{METODE PENELITIAN}

Metode Penelitian yang digunakan adalah deskriptif kualitatif dengan mengumpulkan data primer dan sekunder melalui wawancara, observasi langsung dan mencatat dokumen. Data yang telah diperoleh tersebut kemudian dianalisa secara deskriptif kualitatif. Tujuannya untuk melihat sejauh mana konsep Restorative Justice dan Diversi itu diterapkan oleh penegak hukum sebagaimana diamanatkan oleh UU No. 11 Tahun 2012 tentang Sistem Peradilan Pidana Anak. Penegak hukum yang menjadi sasaran sekaligus menjadi lokasi penelitian adalah Pengadilan Negeri Medan dan Pengadilan Negeri Lubuk Pakam.

\section{HASIL DAN PEMBAHASAN}

Ahli kriminologi berkebangsaan Inggris Tony F. Marshall dalam tulisannya mengemukakan bahwa defenisi restorative justice adalah: ${ }^{7}$

"restorative justice is a process where by all the parties with a stake in a particular offence come together to resolve collectively how to deal with the aftermath of the offence and it's implication for the future" (restorative justice adalah sebuah proses dimana semua pihak yang

6 Paulus Hadisuprapto, Peradilan Restoratif : Model Peradilan Anak Indonesia Masa Depan ,2006,Pidato Pengukuhan Guru Besar Fakultas Hukum Universitas Diponegoro, Badan Penerbit Universitas Diponegoro, Semarang, hlm. 32 .

${ }^{7}$ Tonny F. Marshal dalam bukuMarlina, Pengantar Konsep Diversi dan Restorative Justice dalam Hukum Pidana,USU Press, Medan, 2010, hal. 28 
berkepentingan dalam pelanggaran tertentu bertemu bersama untuk menyelesaikan secara bersama-sama bagaimana menyelesaikan akibat dari pelanggaran tersebut demi kepentingan masa depan)

Restorative justice bersifat merekatkan pada peradilan pidana dengan konteks sosial yang menekan dari pada mengisolasinya secara tertutup. Defenisi yang dikemukakan oleh Tony F. Marshall tersebut sangat membantu dalam membahas Restorative justice meskipun defenisi tersebut masih menimbulkan sejumlah pertanyaan seperti: siapa saja para pihak yang berkepentingan dan terlibat dengan pelanggaran (parties with a stake in the offence)?. Bagaimana mereka mencapai penyelesaian bersama (collective resolution)?. Apakah maksud dari menghadapi akibat buruk dari pelanggaran (deal with the aftermath of the offence)?. Apakah yang menjadi implikasi di masa yang akan datang yang perlu dipertimbangkan (implication for the future)?. Maka jawaban atas pertanyaanpertanyaan tersebut harus dijelaskan dengan kalimat-kalimat secara spesifik.

\section{Konsep Restorative Justice} (Keadilan Restoratif) sebenarnya telah lama dipraktekkan masyarakat adat Indonesia, seperti di Papua, Bali, Toraja, Minangkabau dan komunitas tradisional lain yang masih kuat memegang kebudayaannya. Apabila terjadi suatu tindak pidana oleh seseorang (termasuk perbuatan melawan hukum yang dilakukan anak), penyelesaian sengketa diselesaikan di komunitas adat secara internal tanpa melibatkan aparat negara di dalamnya. Ukuran keadilan bukan berdasarkan keadilan retributif berupa balas dendam atau hukuman penjara, namun berdasarkan keinsyafan dan pemaafan. ${ }^{8}$

Restorative Justice atau keadilan Restoratif adalah suatu proses penyelesaian yang melibatkan pelaku, korban, keluarga mereka dan pihak lain yang terkait dalam suatu tindak pidana, secara bersama sama mencari penyelesaian terhadap tindak pidana tersebut dan implikasinya dengan menekankan pemulihan dan bukan pembalasan. ${ }^{9}$

Diversi adalah suatu pengalihan penyelesaian kasus-kasus anak yang diduga melakukan tindak pidana tertentu dari proses pidana formal ke penyelesaian damai antara tersangka/terdakwa/pelaku tindak pidana dengan korban yang difasilitasi oleh keluarga dan/atau masyarakat, Pembimbing Kemasyarakatan Anak, Polisi, Jaksa atau Hakim. ${ }^{10}$

Semua perkara anak yang berkonflik dengan hukum harus diselesaikan melalui jalur peradilan formal, dan memberikan alternatif bagi penyelesaian dengan pendekatan keadilan restoratif maka, asas perkara anak yang berkonflik dengan hukum dapat dilakukan Diversi demi kepentingan terbaik bagi anak dan dengan mempertimbangkan keadilan bagi korban.

Diversi wajib diupayakan pada tingkat penyidikan, Penuntutan, dan pemeriksaan perkara anak di Pengadilan

8 Ds.Dewi, Restorative Justice, Diversionary Schemd and Special Childre's Courts In Indonesia, www.wordpress.com. Diakses tanggal 23 Mai 2014

9Pasal 1 angka 6 UU Sistem Peradilan Pidana Anak, lihat juga dalam Naskah Akademik RUU Sistem Peradilan Pidana Anak, Hal.48-49.

${ }^{10}$ Dalam Naskah Akademik RUU Sistem Peradilan Pidana Anak, Hal. 48 
Lidya Rahmadhani Hasibuan, Perbandingan Diversi dan Restorative Justice terhadap Anak Berhadapan dengan Hukum di Kota Medan dan Kabupaten Deli Serdang

Negeri.11 Kata "wajib diupayakan" mengandung makna bahwa penegak hukum anak dari penyidik, Penuntut dan juga Hakim diwajibkan untuk melakukan upaya agar proses Diversi bisa dilaksanakan. Hal inilah yang membuat perdebatan dalam panja RUU SPPA, bahwa bagi penegak hukum anak apabila tidak melakukan upaya Diversi haruslah di beri sanksi. ${ }^{12}$ Terkait dengan sanksi pidana (Pasal 96) terjadi perdebatan, di satu pihak yang pro menginginkan agar aparat penegak hukum harus mampu bertanggung jawab atas tindakannya apabila lalai tidak melakukan upaya Diversi, dipihak lain akan mengakibatkan kriminalisasi terhadap aparat penegak hukum. Hal ini yang mungkin akan di judicial review oleh para Hakim karena akan mempengaruhi kinerja dia dalam memeriksa dan memutuskan perkara.

Permasalahan Diversi bahwa kewajiban mengupayakan Diversi dari mulai penyidikan, Penuntutan dan pemeriksaan perkara anak di Pengadilan Negeri, dilaksanakan dalam hal tindak pidana yang dilakukan: (a) diancam dengan pidana penjara dibawah 7 (tujuh) tahun; dan (b) bukan merupakan pengulang tindak pidana.13

Ketentuan ini menjelaskan bahwa anak yang melakukan tindak pidana yang ancamanya lebih dari 7 (tujuh) tahun dan merupakan seorang pengulang maka tidak wajib diupayakan Diversi, hal ini memang

\footnotetext{
11Lihat Pasal 7 ayat (1) UU No.11 Tahun 2012 tentang Sistem Peradilan Pidana Anak

12 Lihat Pasal 95 UU Sistem Peradilan Pidana Anak yang memberikan ancaman sanksi administratif dan Pasal 96 UU Sistem Peradilan Pidana Anak yang memberikan ancaman pidana penjara paling lama 2 tahun dan denda paling banyak Rp.200.000.000 Pidana Anak
}

penting mengingat kalau ancamannya lebih dari 7 (tujuh) tahun tergolong pada tindak pidana yang berat, dan merupakan suatu pengulangan, artinya anak pernah melakukan tindak pidana itu sejenis maupun tidak sejenis termasuk tindak pidana yang diselesaikan melalui Diversi. Pengulangan tindak pidana oleh anak, menjadi bukti bahwa tujuan Diversi tidak tercapai yakni menanamkan rasa tanggung jawab kepada anak untuk tidak mengulangi perbuatan yang berupa tindakan pidana. Upaya Diversi terhadapnya bisa saja tidak wajib diupayakan.

Proses Diversi dilakukan melalui musyawarah dengan melibatkan anak dan orang tua/walinya, pembimbing kemasyarakatan, dan Pekerja Profesional berdasarkan pendekatan keadilan restoratif. ${ }^{14}$ Selain itu dalam hal diperlukan musyawarah tersebut juga dapat melibatkan Tenaga Kesejahteraan Sosial, dan atau masyarakat. ${ }^{15}$

Proses Diversi sendiri wajib memperhatikan: ${ }^{16}$
a. Kepentingan korban;
b. Kesejahteraan dan tanggung jawab anak;
c. Penghindaran stigma negatif;
d. Penghindaran pembalasan;
e. Keharmonisan masyarakat;
f. Kepatutan, kesusilaan, dan ketertiban umum.

Pada proses penegakan hukum pidana anak, maka aparat baik itu Penyidik, Penuntut Umum, dan Hakim

\footnotetext{
14 Lihat Pasal 8 ayat (1) UU Sistem Peradilan Pidana Anak

15 Pasal 8 ayat (2) UU Sistem Peradilan Pidana Anak

16Pasal 8 ayat (3) UU Sistem Peradilan Pidana Anak
} 
dalam melakukan Diversi harus mempertimbangkan kategori tindak pidana, umur anak, hasil penelitian kemasyarakatan dari Bapas dan dukungan lingkungan keluarga dan masyarakat. ${ }^{17}$

Kesepakatan Diversi harus mendapatkan persetujuan korban dan atau keluarga anak korban serta kesediaan anak dan keluarganya. Hal ini mengindikasikan bahwa harus ada keaktifan dari korban dan keluargannya dalam proses Diversi, agar proses pemulihan keadaan dapat tercapai sesuai dengan keadilan restoratif. Kesepakatan Diversi tersebut dapat dikecualikan untuk (a) tindak pidana ringan, (b) tindak pidana ringan, (c) tindak pidana tanpa korban, dan (d) nilai kerugian korban tidak lebih dari nilai upah minimum propinsi setempat. ${ }^{18}$

Bentuk-bentuk hasil kesepakatan Diversi antara lain dapat berupa: ${ }^{19}$

a. Perdamaian dengan atau tanpa ganti kerugian;

b. Penyerahan kembali kepada orang tua/wali;

c. Keikutsertaan dalam pendidikan atau pelatihan di lembaga pendidikan atau LPKS paling lama 3 bulan; atau

d. Pelayanan masyarakat.

Hasil kesepakatan tersebut dituangkan dalam bentuk kesepakatan Diversi. Apabila proses Diversi tidak menghasilkan kesepakatan atau tidak dilaksanakan, maka proses peradilan

Anak

Anak

17 Pasal 9 ayat (1) UU Sistem Peradilan Pidana 18 Pasal 9 ayat (2) UU Sistem Peradilan Pidana ${ }^{19}$ Pasal 11 UU Sistem Peradilan Pidana Anak pidana anak dilanjutkan untuk setiap tingkatannya. ${ }^{20}$

Pada Tahun 2013 dan 2014, Pengadilan Negeri Medan memiliki kasus sebanyak;

\begin{tabular}{|l|lr|c|c|}
\hline No & Uraian & Masuk & Keterangan \\
\hline 1 & Jumlah & Kasus & 104 & \\
& Tahun & 2013 & & \\
& (Januari r.d & & \\
& Desember 2013) & & \\
\hline 2 & Jumlah & Kasus & 62 & \\
& $\begin{array}{l}\text { Tahun 2014 } \\
\text { (januari s.d Agustus }\end{array}$ & & \\
& 2014) & & \\
\hline 3 & $\begin{array}{l}\text { Jumlah Kasus } \\
\text { Tahun 2015- Tahun }\end{array}$ & 231 & \\
& $\begin{array}{l}\text { 2017 (Januarirr.d. } \\
\text { Agustus 2017) }\end{array}$ & \\
\hline & Total & $\mathbf{3 9 7}$ & \\
\hline
\end{tabular}

Sumber : Data PN Medan

Pada Tahun 2013 dan 2014, Pengadilan Negeri Lubuk Pakam, pengadilan negeri di Kabupaten Deli Serdang memiliki kasus sebanyak :

\begin{tabular}{|l|l|c|c|c|}
\hline No & Uraian & Masuk & Putus & Keterangan \\
\hline 1 & Jumlah & 126 & 117 & \\
& Kasus & & & \\
& Tahun & & & \\
& 2013 \\
& Januari s.d & & & \\
& $\begin{array}{l}\text { Desember } \\
\text { 2013) }\end{array}$ & & & \\
\hline 2 & $\begin{array}{l}\text { Jumlah } \\
\text { Kasus } \\
\text { Tahun } \\
\text { 2014 } \\
\text { januari s.d } \\
\text { Agustus }\end{array}$ & 58 & 29 & \\
& 2014 ) & & & \\
\hline 3. & Jumlah & 193 & 178 & \\
& Kasus & & \\
& Tahun & & & \\
& 2015 & & \\
& Tahun & & & \\
\hline
\end{tabular}
20Pasal 13 UU Sistem Peradilan Pidana Anak 
Lidya Rahmadhani Hasibuan, Perbandingan Diversi dan Restorative Justice terhadap Anak Berhadapan dengan Hukum di Kota Medan dan Kabupaten Deli Serdang

\begin{tabular}{|l|l|l|l|l|}
\hline $\begin{array}{l}2017 \\
\text { (januari s.d } \\
\text { Agustus } \\
\text { 2017) }\end{array}$ & & & \\
\hline Total & $\mathbf{3 7 7}$ & $\mathbf{3 2 4}$ & \\
\hline
\end{tabular}

Tabel Perbedaan UU No 3 Tahun 1997 dan UU No 11 Tahun 2012

\begin{tabular}{|c|c|c|c|c|c|}
\hline \multirow{2}{*}{ Perbedaan } & \multirow{2}{*}{$\begin{array}{c}\text { UU No } 3 \\
\text { Tahun } 1997\end{array}$} & \multirow{2}{*}{$\begin{array}{c}\text { UU No } 11 \text { Tahun } \\
2012\end{array}$} & & & pembalasan." \\
\hline & & & \multirow{4}{*}{$\begin{array}{l}\text { Sanksi } \\
\text { pidana }\end{array}$} & \multirow[b]{2}{*}{$\begin{array}{l}\text { Pidana Pokok } \\
\text { a. pidana } \\
\text { penjara; } \\
\text { b. pidana } \\
\text { kurungan; } \\
\text { c. pidana } \\
\text { denda; } \\
\text { atau } \\
\text { d. pidana } \\
\text { pengawasa } \\
\text { n. }\end{array}$} & \multirow{3}{*}{$\begin{array}{l}\text { Pidana Pokok } \\
\text { a. pidana } \\
\text { peringatan; } \\
\text { b. pidana dengan } \\
\text { syarat: } \\
\text { 1) pembinaan di } \\
\text { luar lembaga; } \\
\text { 2) pelayanan } \\
\text { masyarakat; } \\
\text { atau } \\
\text { 3) pengawasan. } \\
\text { c. pelatihan kerja; } \\
\text { d. pembinaan } \\
\text { dalam lembaga; } \\
\text { dan } \\
\text { e. penjara. }\end{array}$} \\
\hline $\begin{array}{l}\text { Definisi } \\
\text { anak }\end{array}$ & $\begin{array}{lr}\text { Anak, } & \text { Anak } \\
\text { Nakal, } & \text { dan } \\
\text { Anak } & \text { Didik } \\
\text { Pemasyarakat } \\
\text { an. }\end{array}$ & $\begin{array}{lr}\text { Anak } & \text { yang } \\
\text { Berhadapan } & \\
\text { dengan Hukum, } & \text { Hnak } \\
\text { Anak } & \text { yerkonflik dengan } \\
\text { Hukum, Anak yang } \\
\text { Menjadi Korban } \\
\text { Tindak Pidana, dan } \\
\text { Anak yang } & \text { Menjadi } \\
\text { Saksi rindak } \\
\text { Pidana }\end{array}$ & & & \\
\hline $\begin{array}{l}\text { Lembaga- } \\
\text { lembaga } \\
\text { anak }\end{array}$ & \begin{tabular}{lr}
\multicolumn{2}{l}{ Lembaga } \\
Pemasyarakat \\
an; merujuk \\
pada $\quad$ UU \\
Pemasyarakat \\
an
\end{tabular} & $\begin{array}{l}\text { Lembaga } \\
\text { Pembinaan Khusus } \\
\text { Anak (LPKA), } \\
\text { Lembaga } \\
\text { Penempatan Anak } \\
\text { Sementara (LPAS), } \\
\text { dan Lembaga } \\
\text { Penyelenggaraan } \\
\text { Kesejahteraan } \\
\text { Sosial (LPKS) }\end{array}$ & & $\begin{array}{l}\text { Pidana } \\
\text { Tambahan } \\
\text { a. perampasa } \\
\text { n barang- } \\
\text { barang } \\
\text { tertentu } \\
\text { dan atau } \\
\text { b. pembayara } \\
\text { n ganti } \\
\text { rugi. }\end{array}$ & \\
\hline \multirow[t]{3}{*}{ Asas-asas } & \multirow{3}{*}{$\begin{array}{l}\text { Tidak } \\
\text { disebutkan } \\
\text { secara } \\
\text { eksplisit }\end{array}$} & \multirow{3}{*}{\begin{tabular}{|ll}
\multicolumn{2}{l}{ Pasal } \\
menyebutkan asas \\
a. \\
b. \\
c. & nelindungan; \\
& $;$ \\
d. & kepentingan; \\
& terbaik bagi \\
& Anak; \\
e. & penghargaan \\
& terhadap \\
& pendapat Anak; \\
f. & kelangsungan \\
& hidup dan \\
& tumbuh \\
& kembang Anak;
\end{tabular}} & & & $\begin{array}{l}\text { pidana; atau } \\
\text { b. pemenuhan } \\
\text { kewajiban adat. }\end{array}$ \\
\hline & & & $\begin{array}{l}\text { Ketentuan } \\
\text { pidana }\end{array}$ & $\begin{array}{l}\text { Tidak } \\
\text { menyebutkan }\end{array}$ & 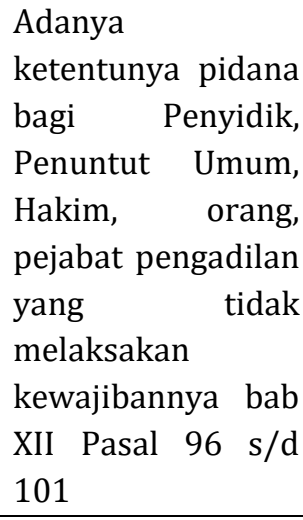 \\
\hline & & & & & \\
\hline
\end{tabular}
terakhir; dan penghindaran pembalasan."

pidana pidana dengan pembinaan di pelayanan masyarakat; atau c. pelatihan kerja; pembinaan dalam lembaga; dan

perampasa $n$ barangbarang tertentu pembayara n ganti dari tindak pemenuhan

ketentunya pidana bagi Penyidik, Penuntut Umum, Hakim, orang, pejabat pengadilan yang tidak melaksakan kewajibannya bab XII Pasal 96 s/d

g. pembinaan dan pembimbingan Anak;

h. proporsional;

i. perampasan kemerdekaan dan pemidanaan sebagai upaya

(n)

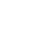


Merujuk pada tabel perbedaan diatas maka terlihat bahwa sebelum berlakunya UU No. 11 tahun 2012 tentang Sistem Peradilan Pidana Anak (SPPA), penerapan Diversi dan Restorative Justice terhadap anak pelaku tindak pidana dalam proses hukum belum menjadi hal yang "harus dijalankan oleh Hakim "sebagai pengambil keputusan akhir. Hal ini seperti yang disampaikan oleh hakim-hakim di Pengadilan Negeri di Medan dan Lubuk Pakam yang diwawancara oleh Peneliti.

Hakim di PN Medan menyebutkan bahwa beliau memang pernah mengusahakan pidana sebagai upaya terakhir bagi anak. Namun harus mempertimbangkan jenis kasus yang terjadi. Selanjutnya akan menjadi pertimbangan apakah berdasarkan pemeriksaan persidangan dapat atau tidaknya untuk dipidana atau setidaktidaknya diperingan pidananya (alasan pemaaf). Hal ini tetap mengarah pada pemberian efek jera bagi pelaku. Namun, terkadang pemikiran anak (biasanya berusia 16 tahun ke atas) sudah bukan layaknya pemikiran seorang anak lagi karena mereka mampu membuat perencanaan tindak pidana (bukan lagi sekedar kenakalan pencurian biasa dll). Lebih lanjut beliau menyebutkan bahwa pada Pasal 4 berdasarkan UU nomor 3 tahun 1997 pernah dijadikan dasar dalam memutus kasus pencurian anak (dalam karir saya sebagai hakim), tapi putusan itu bukan di PN Medan, dimana pada saat itu diputus oleh hakim adalah bahwa anak dikembalikan kepada orangtuanya (tidakan). Sementara UU yg baru ini menekankan agar pidana itu benar benar upaya hukum terakhir bagi anak dan itu bersifat wajib. ${ }^{21}$

Hal senada disampaikan oleh seorang Hakim di Pengadilan Negeri Lubuk Pakam, beliau menyampaikan bahwa Hakim walaupun berpegang pada UU No. 3 tahun 1997 tapi hakim selalu berusaha untuk mengusahakan adanya perdamaian untuk pelaku anak. Karena untuk kasus ringan seperti pencurian diusahakan untuk berdamai. Itulah upaya hakim untuk menegakan asas ultimum remedium. Pada saat persidangan tetap terus diusahakan perdamaian, hakim aktif untuk melakukan damai. Hakim berdiskusi dengan hakim di Medan yang pada intinya hakim sama Cuma untuk keaktifan hakim di Medan kurang karena banyaknya jumlah kasus anak di Medan. Tapi kalau di Pakam hakim lebih aktif dan terus berusaha anak didamaikan dengan pihak korbannya. ${ }^{22}$

\section{SIMPULAN}

Berdasarkan hasil penelitian yang dapat disimpulkan bahwa Semua Hakim di PN Medan dan Lubuk Pakam memahami konsep Diversi dan Restoratif Justice bagi anak pelaku tindak pidana. Sebelum pemberlakuan UU No. 11 Tahun 2011 tentang Sistem Peradilan Pidana Anak (SPPA), hakim-hakim anak pada pengadilan Negeri Lubuk Pakam dan Medan mempergunakan Undang-undang No. 3 tahun 1997 tentang Pengadilan Anak yang tidak secara eksplisit menyebutkan

21 Wawancara dengan hakim dilakukan pada tanggal 11 Februari 2017 di Pengadilan Negeri Medan. 22 Wawancara dengan hakim dilakukan pada tanggal 14 Maret 2017 di Pengadilan Negeri Lubuk Pakam. 
Lidya Rahmadhani Hasibuan, Perbandingan Diversi dan Restorative Justice terhadap Anak Berhadapan dengan Hukum di Kota Medan dan Kabupaten Deli Serdang

keharusan penerapan Asas Ultimum remedium.

Meskipun belum menerapkan konsep Diversi , Hakim di PN Medan dan Pengadilan Deli Serdang mulai menginisiasi atau memulai penggunaan asas ultimum remedium dengan menawarkan kepada para pihak yaitu terdakwa dan keluarga serta korban dan keluarga untuk membuat perdamaian.

Hakim Anak pada PN Lubuk Pakam menemukan kendala dalam menggunakan konsep Diversi dan Restorative Justice yaitu: Menghadirkan para pihak (sarana dan prasarana tidak memadai) dikarenakan keterbatasan staf BAPAS, biaya dan lainnya; Korban tidak dapat memaafkan pelaku dikarenakan sakit hati; Peran aktif Hakim untuk mewujudkan perdamaian antara pihak (pelaku dan Pelaku serta keluarganya).

Anak-anak pelaku tindak pidana yang berada di LAPAS Anak Tanjung Gusta berharap bahwa konsep Diversi dan Restorative Justice dapat segera diterapkan bagi anak pelaku tindak pidana.

\section{DAFTAR PUSTAKA}

Barda Nawawi Arief, 1992. Bunga Rampai Hukum Pidana, Bandung: Alumni.

Bismar Siregar,1986. Hukum Dan Hak-Hak Anak, Jakarta: Rajawali Press.

HB. Sutopo, 2002, Metodologi Penelitian Kualitatif, Sebelas Maret University Press, Surakarta.

John E.B Myers, 2006. Child Protection in America: Past, Present and Future, New York: Oxford University Press.

Maidin Gultom, 2008. Perlindungan Hukum Terhadap Anak Dalam Sistem Peradilan Pidana Anak Di Indonesia, Bandung: PT. Refika Aditama.

Marlina, 2009. Peradilan Pidana Anak di Indonesia Pengembangan Konsep Diversi dan Restorative Justice, Bandung: PT. Refika Aditama.
Marlina, 2010. Pengantar Konsep Diversi Dan Restorative Justice Dalam Hukum Pidana, Stabat: USU Press.

Norman K. Dezin, 1973. Children and their Cartakers, New Jersey: Transaction Books Rutgers University.

Rini Utami Azis, 2006. Jangan Biarkan Anak Kita Berperilaku Menyimpang, Solo: Tiga Serangkai.

Sudarto, 2006. Kapita Selekta Hukum Pidana, Bandung: Alumni.

Sumaryono, 1995. Etika Profesi Hukum, Yogyakarta: Kanisius.

Travis Hirschi, 2009. Causes of Delinquency, New Jersey: Transactional Publisher.

Wagiati Soetodjo, 2008. Hukum Pidana Anak, Bandung: PT. Refika Aditama.

Winarni. Surachamad, 1985, Dasar-dasar Teknis Research Pengantar Metodologi Ilmiah, Tarsito, Bandung.

Apong Herlina, Makalah Penanganan Anak Yang Berhadapan Dengan Hukum, Komisi Perlindungan Anak Indonesia (KPAI), 2012

Tempo, "Stabat Kota Tertinggi Anak yang Berkonflik Dengan Hukum" http://www.tempo.co diakses pada hari Minggu tanggal 03 Maret 2013 pukul 11.00 wib

Anggara, "Tujuan Pemidanaan" dalam http://anggara.files.wordpress.com. diakses pada hari Minggu tanggal 03 Maret 2013 pukul $11.00 \mathrm{wib}$

Riza Alifianto Kurniawan, "Asas Ultimum Remedium Dalam Pemidanaan Anak Nakal" dalam http://journal.lib.unair.ac.id diakses pada hari Minggu tanggal 03 Maret 2013 pukul 11.00 wib 